\title{
DISIPLIN APARATUR DINAS PEKERJAAN UMUM KABUPATEN SINTANG DALAM PENYELENGGARAAN PEMERINTAHAN
}

\author{
Robert Hoffman \\ Fakultas Hukum Universitas Kapuas Sintang \\ Jalan Oevang Oeray 92 Sintang \\ Email : tobingunka@gmail.com dan tobing_unka@yahoo.com
}

\begin{abstract}
The implementation of government and national development mainly lies in the perfection of the state apparatus more specifically is the government official who is the largest element in the state apparatus. Government employees in addition to demanded and needed in terms of quantity is also sufficient to be addressed with work performance in carrying out duties and responsibilities.
\end{abstract}

Many factors affect the performance of employees either coming from within the employees or from the organization where employees work, one of which is a discipline factor. An employee will only display a good performance or satisfactory if the relevant has a high discipline. The discipline of the apparatus in the administration includes the discipline of punctual work and discipline to complete the work.

Keywords : Discipline, Government. pembangunan nasional terutama terletak pada kesempurnaan aparatur negara lebih khusus lagi ialah pegawai pemerintahan yang merupakan unsur terbesar dalam aparatur negara. Pegawai pemerintahan disamping dituntut dan dibutuhkan dalam segi kuantitasnya yang mencukupi juga ditujukan dengan prestasi kerja dalam menjalankan tugas dan tanggung jawabnya.

Banyak faktor yang mempengaruhi kinerja pegawai baik yang berasal dari dalam diri pegawai maupun yang berasal dari organisasi tempat pegawai bekerja, salah satunya faktor disiplin. Seorang pegawai hanya akan menampilkan kinerja yang baik atau memuaskan jika yang bersangkutan memiliki disiplin tinggi. Disiplin aparatur dalam penyelenggaraan pemerintahan meliputi disiplin kerja tepat waktu dan disiplin untuk menyelesaikan pekerjaan.

Kata Kunci : Disiplin, Pemerintahan.

\section{Latar Belakang}

Abstrak

Sumber

Daya Manusia

$(\mathrm{SDM})$

merupakan unsur yang sangat primer dalam 
suatu organisasi sebab organisasi merupakan kesatuan sosial terdiri dari orang atau kelompok orang yang berinteraksi satu sama lain. Oleh karena itu setiap organisasi selalu berupaya untuk memiliki SDM yang berkualitas, karena tanpa SDM yang berkualitas suatu organisasi tidak akan berjalan dengan baik, termasuk didalamnya organisasi sektor publik seperti pemerintah yang dituntut untuk memiliki SDM yang berkualitas.

Keberadaan pegawai yang bekerja di lembaga atau instansi pemerintahan baik berstatus sebagai pegawai negeri sipil (PNS) maupun Non PNS merupakan salah satu kunci keberhasilan pembangunan nasional. Peran pegawai, sebagaimana dinyatakan dalam Undang-Undang Nomor 43 Tahun 1999 tentang Perubahan Atas UndangUndang Nomor 8 Tahun 1974 Tentang PokokPokok Kepegawaian adalah mewujudkan masyarakat madani yang taat hukum, berperadaban modern, demokratis, makmur, adil dan bermoral tinggi, dengan tugas sebagai abdi masyarakat yang menyelenggarakan pelayanan secara adil dan merata, menjaga persatuan dan kesatuan bangsa dengan penuh kesetiaan kepada Pancasila dan UUD 1945. Jadi, tolok ukur keberhasilan pembangunan nasional salah satunya berasal dari peran pegawai yang bekerja di lembaga atau instansi-instansi pemerintahan.
Disamping itu peningkatan kualitas kinerja pegawai pemerintahan juga diharapkan dapat mendukung pelaksanaan administrasi pemerintahan sehingga dapat berjalan efektif. Pegawai pemerintahan sebagai sumber daya manusia dalam birokrasi pemerintahan yang handal dan profesional merupakan suatu keharusan agar tanggung jawab penyelenggaraan pemerintahan dan pembangunan dapat terlaksana dengan baik. Peningkatan kualitas sumber daya manusia aparatur menjadi tantangan dalam menghadapi paradigma baru pemerintahan dan pembangunan nasional.

Pembangunan sumber daya manusia aparatur negara mempunyai peranan yang menentukan keberhasilan penyelenggaraan pemerintahan dan pembangunan. Tersedianya aparatur pemerintah yang profesional dan berkualitas adalah sangat menentukan, agar masing-masing aparatur pemerintah mampu mempersiapkan diri memasuki era pemerintahan yang kompetitif. Untuk itu, aparatur negara dituntut untuk bersikap dan berperilaku yang penuh dengan kesetiaan dan ketaatan pada negara, bermoral, bermental baik, profesional, sadar akan tanggung jawab sebagai pelayanan publik, serta mampu menjadi perekat persatuan dan kesatuan bangsa.

Selain itu, pembinaan aparatur 
negara lebih diarahkan pada peningkatan kualitas, efisiensi dan efektifitas seluruh tatanan manajemen pemerintahan termasuk peningkatan kemampuan, disiplin dan ketauladanan agar seluruh aparatur negara semakin mampu melaksanakan tugas-tugas umum pemerintahan, pembangunan dan pembinaan masyarakat menuju perwujudan kepemerintahan yang baik. Sehingga kinerja pegawai pemerintahan sebagai sumber daya manusia yang dimiliki organisasi merupakan suatu hal yang sangat penting untuk diperhatikan pihak organisasi terutama dalam upayanya untuk mencapai tujuan yang telah ditetapkan.

Disiplin merupakan daya dorong bagi seseorang untuk memberikan kontribusi yang sebesar mungkin demi keberhasilan organisasi mencapai tujuannya. Dengan adanya disiplin kerja yang tinggi maka dapat diharapkan pegawai mempunyai kemauan yang tinggi untuk melaksanakan pekerjaannya dengan baik berpengaruh terhadap peningkatan kinerja pegawai. Faktor disiplin menjadi faktor penting yang berpengaruh terhadap kinerja pegawai. Kinerja pegawai akan mempengaruhi keberhasilan suatu organisasi dalam mencapai tujuannya, karena pegawai sebagai penggerak dalam organisasi, sehingga sukses tidaknya suatu organisasi akan sangat tergantung pada kinerja pegawainya.
Berdasarkan pengamatan sementara diperoleh bahwa disiplin kerja pegawai pada Dinas Pekerjaan Umum Kabupaten Sintang pada dasarnya sudah cukup baik, terlihat dari sikap pegawai yang telah melaksanakan pekerjaannya sesuai dengan tugas pokok dan fungsinya (tupoksi). Namun, sebagai manusia maka pegawai di Dinas Pekerjaan Umum Kabupaten Sintang juga pernah mengalami pasang surutnya disiplin kerja. Rutinitas sama yang dilakukan pegawai setiap hari seringkali menyebabkan turunnya disiplin kerja, yang ditunjukkan diantaranya dengan rasa malas pegawai melaksanakan dan menyelesaikan pekerjaannya. Hal ini tentu berimbas pada penurunan kinerja pegawai yang bersangkutan. Oleh karena itu, kantor Dinas Pekerjaan Umum Kabupaten Sintang terus berupaya meningkatkan disiplin kerja para pegawainya, guna mencapai kinerja yang optimal. Sejalan dengan kondisi tersebut, maka peneliti tertarik untuk meneliti tentang "Disiplin Aparatur Dinas Pekerjaan Umum Kabupaten Sintang Dalam Penyelenggaraan Pemerintahan.”

\section{Pembahasan}

\section{A. Deskripsi Wilayah Penelitian}

Kabupaten Sintang terletak di bagian timur Provinsi Kalimantan Barat atau di antara $1^{\circ} 05^{\prime}$ Lintang Utara serta $0^{\circ} 46^{\prime}$ Lintang 
Selatan dan $110^{\circ} 50^{\prime}$ Bujur Timur serta $113^{\circ} 20^{\prime}$

Bujur Timur. Batas wilayah administratif Kabupaten Sintang yaitu : sebelah utara berbatasan dengan Kabupaten Kapuas Hulu dan Malaysia Timur(Serawak), sebelah selatan berbatasan dengan Propinsi Kalimantan Tengah, Kabupaten Melawi, Kabupaten Sanggau dan Kabupaten Ketapang, sebelah timur berbatasan dengan Propinsi Kalimantan Tengah, Kabupaten Sanggau dan Kabupaten Kapuas Hulu, sebelah barat berbatasan dengan Kabupaten Ketapang, Kabupaten Sanggau, Kabupaten Melawi, Kabupaten Kapuas Hulu dan Kabupaten Sekadau.

Kabupaten Sintang merupakan kabupaten yang memiliki luas wilayah ketiga terbesar di Propinsi Kalimantan Barat setelah Kabupaten Ketapang dan Kabupaten Kapuas Hulu. Berdasarkan data Kabupaten Sintang dinyatakan bahwa luas wilayah Kabupaten Sintang yaitu : $21.635 \mathrm{~km} 2$ dengan wilayah terluas terdapat di Kecamatan Ambalau yaitu : 6.386,40 km2 atau sebesar 29,52 persen, sedangkan Kecamatan Sintang merupakan wilayah kecamatan yang terkecil dengan luas wilayahnya yaitu $277,05 \mathrm{~km} 2$ atau hanya sebesar 1,28 persen. Dari luas tersebut, sebagian besar merupakan wilayah perbukitan dengan luas sekitar $13.573,75 \mathrm{~km} 2$ atau 62,74 persen.

Kabupaten Sintang memiliki potensi alam yang dapat dijadikan objek wisata berupa air terjun sebanyak 19 air terjun yang tersebar di 5 (lima) kecamatan. Kecamatan-kecamatan yang memiliki air terjun yaitu : Sepauk, Kayan Hulu, Ambalau, Ketungau Tengah dan Ketungau Hulu. Kabupaten Sintang juga memiliki 4 (empat) gunung yang terdapat di 2 (dua) kecamatan yaitu Kecamatan Serawai dan Kecamatan Ambalau. Berdasarkan data Kabupaten Sintang bahwa secara administratif, Pemerintahan Kabupaten Sintang terdiri dari 14 Kecamatan yang terbagi menjadi 281 desa dan 6 kelurahan. Jumlah penduduk Kabupaten Sintang saat ini mencapai 365.058 jiwa.

Dinas Pekerjaan Umum Kabupaten Sintang yang terletak di Jalan Moch. Saad, Sintang, Propinsi Kalimantan Barat merupakan salah satu perangkat daerah Pemerintah Kabupaten Sintang yang dibentuk berdasarkan Peraturan Bupati Sintang Nomor 45 Tahun 2013 tentang Susunan Organisasi dan Tata Kerja Dinas Pekerjaan Umum Kabupaten Sintang.

Dinas Pekerjaan Umum Kabupaten Sintang dalam melaksanakan tugas pokok tersebut, menyelenggarakan 16 fungsi sebagaimana dijabarkan dalam tabel berikut ini: 
Tabel. 1. Tugas Pokok dan Fungsi Dinas

Pekerjaan Umum Kabupaten Sintang.

\begin{tabular}{|c|c|}
\hline Tugas Pokok & Fungsi \\
\hline $\begin{array}{l}\text { Melaksanakan } \\
\text { sebagian } \\
\text { kewenangan } \\
\text { otonomi daerah } \\
\text { di bidang } \\
\text { pekerjaan umum. }\end{array}$ & 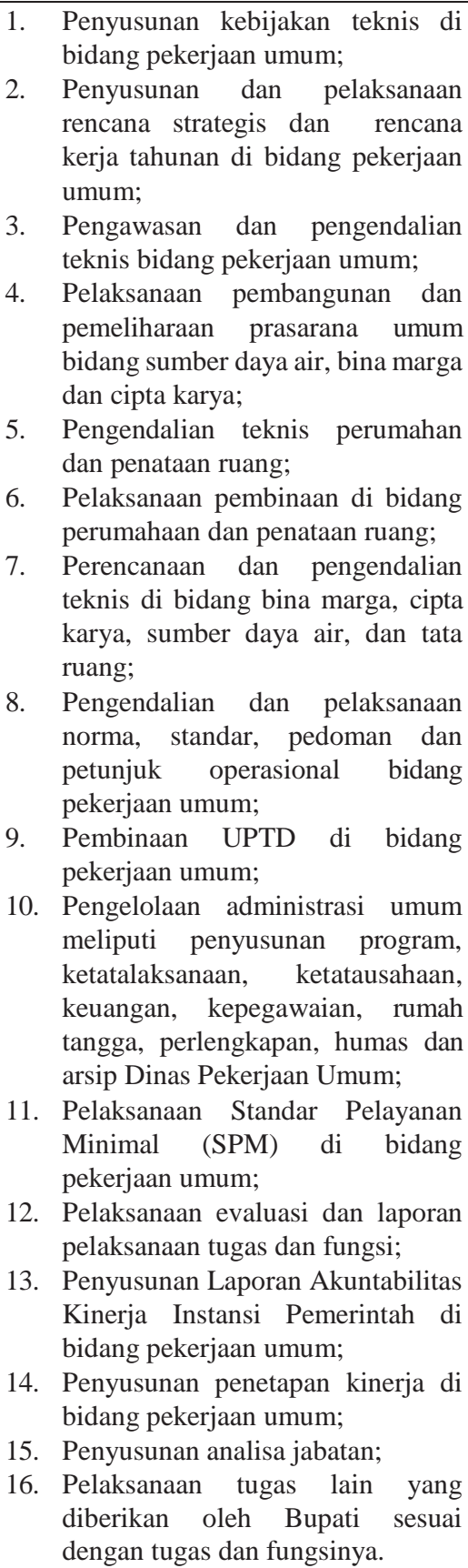 \\
\hline
\end{tabular}

\section{Sumber Data : Dinas Pekerjaan Umum}

\section{Kabupaten Sintang.}

Dari tabel tersebut terlihat bahwa

Dinas Pekerjaan Umum Kabupaten Sintang dalam menyelenggarakan ke-16 fungsinya, pada hakikatnya memiliki 7 (tujuh) landasan fungsi yang meliputi fungsi : penyusunan, pelaksanaan, pengendalian, pengawasan, perencanaan, pembinaan dan pengelolaan, sebagaimana dipaparkan dalam tabel berikut ini.

Tabel 2. Landasan Fungsi Dinas Pekerjaan Umum Kabupaten Sintang.

\begin{tabular}{|c|c|c|c|}
\hline No & $\begin{array}{c}\text { Landasan } \\
\text { Fungsi } \\
\end{array}$ & Kegiatan & $\begin{array}{c}\text { Jum- } \\
\text { lah }\end{array}$ \\
\hline 1. & Penyusunan & 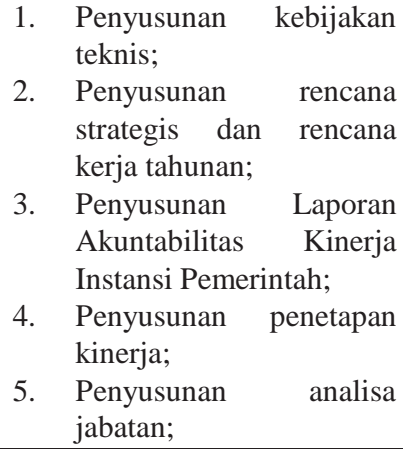 & 5 \\
\hline 2. & Pelaksanaan & $\begin{array}{l}\text { 1. } \begin{array}{l}\text { P e l a k s a n a a n } \\
\text { pembangunan } \\
\text { pemeliharaan; }\end{array} \\
\text { 2. } \begin{array}{l}\text { Pelaksanaan Standar } \\
\text { Pelayanan Minimal } \\
\text { (SPM); }\end{array} \\
\text { 3. Pelaksanaan evaluasi } \\
\text { dan laporan pelaksanaan } \\
\text { tugas dan fungsi; } \\
\text { 4. Pelaksanaan rencana } \\
\text { strategis dan rencana } \\
\text { kerja tahunan; } \\
\text { 5. Pelaksanaan tugas lain } \\
\text { yang diberikan oleh } \\
\text { Bupati sesuai dengan } \\
\text { tugas dan fungsinya. } \\
\text { 6. Pelaksanaan norma, } \\
\text { standar, pedoman dan } \\
\text { petunjuk operasional. }\end{array}$ & 6 \\
\hline 3. & Pengendalian & $\begin{array}{l}\text { 1. Pengendalian teknis; } \\
\text { 2. Pengendalian norma, } \\
\text { standar, pedoman dan } \\
\text { petunjuk operasional; }\end{array}$ & 2 \\
\hline 4. & Pengawasan & 1. Pengawasan teknis; & 1 \\
\hline 5. & Perencanaan & 1. Perencanaan teknis; & 1 \\
\hline 6. & Pembinaan & 1. $\quad$ Pembinaan UPTD; & 1 \\
\hline 7. & Pengelolaan & 1. Pengelolaan; & 1 \\
\hline
\end{tabular}

\section{Sumber Data : Fungsi Dinas Pekerjaan}

Umum Kabupaten Sintang (setelah diolah).

Daritabeltersebut,penelitiberpendapat

bahwa dengan adanya 7 landasan fungsi yang dimiliki oleh Dinas Pekerjaan Umum 
Kabupaten Sintang tersebut menandakan tanggungjawab Dinas Pekerjaan Umum cukup berat. Oleh karena itu sangat tepatlah jika Dinas Pekerjaan Umum Kabupaten Sintang menaruh perhatian yang cukup besarterhadap pelaksanaan tugas pokok dan fungsi yang dimilikinya dalam bidang pekerjaan umum.

Struktur organisasi Dinas Pekerjaan Umum Kabupaten Sintang berdasarkan Peraturan Bupati Sintang Nomor 45 Tahun 2013 tentang Susunan Organisasi dan Tata Kerja Dinas Pekerjaan Umum Kabupaten Sintang, terdiri dari :

1. Kepala Dinas

2. Sekretariat, terdiri dari :

a. Sub Bagian Keuangan dan Program

b. Sub Bagian Aparatur dan Umum

c. Sub Bagian Perlengkapan

3. Bidang Cipta Karya, terdiri dari :

a. Seksi Pembangunan Gedung dan Perumahan

b. Seksi Pemukiman, Perumahan, dan Penyehatan Lingkungan

c. Seksi Perencanaan Teknis Cipta Karya

4. Bidang Bina Marga, terdiri dari :

a. Seksi Pemeliharaan Jalan dan Jembatan

b. Seksi Pembangunan Peningkatan Jalan dan Jembatan

c. Seksi Perencanaan Teknis Bina Marga

5. Bidang Sumber Daya Air, terdiri dari :

a. Seksi Pembangunan Sumber Daya Air

b. Seksi Pemeliharaan Sumber Daya Air

c. Seksi Perencanaan Teknis Sumber Daya Air

6. Bidang Tata Ruang, terdiri dari : a. Seksi Perencanaan Penataan Ruang Kabupaten

b. Seksi Penataan Bangunan dan Lingkungan

c. Seksi Tata Kota

7. Unit Pelaksana Teknis Daerah(UPTD)

8. Kelompok Jabatan Fungsional.

Tugas pokok dan fungsi masingmasing pejabat struktural di Dinas Pekerjaan Umum Kabupaten Sintang berdasarkan Peraturan Bupati Sintang Nomor 45 Tahun 2013 tentang Susunan Organisasi dan Tata Kerja Dinas Pekerjaan Umum Kabupaten Sintang, sebagaimana dikemukakan oleh Kepala Dinas Pekerjaan Umum Kabupaten Sintang kepada peneliti dalam wawancara, adalah sebagai berikut : Tugas pokok Kepala Dinas Pekerjaan Umum Kabupaten Sintang adalah membantu Bupati Sintang dalam bidang pekerjaan umum, sedangkan yang menjadi Fungsinya adalah :

1. Pengoordinasian bidang kesekretariatan, bidang cipta karya, bidang bina marga, bidang sumber daya air dan bidang tata ruang;

2. Penyampaian program kerja Dinas Pekerjaan Umum kepada Bupati;

3. Penjabaran kebijakan sesuai bidang tugas Pekerjaan Umum;

4. Pengendalian dan pelaksanaan pekerjaan umum serta perijinan dan pengawasan pemanfaatan jalan beserta kualitasnya;

5. Pembinaan UPTD di bidang Pekerjaan Umum;

6. Menetapkan pedoman dan petunjuk teknis penyelenggaraan urusan lingkup bidang tata ruang dan tata kota;

7. Pelaksanaan Standar Pelayanan 
Minimal (SPM) di bidang Pekerjaan

Umum;

8. Penetapan kinerja di bidang Pekerjaan Umum;

9. Penyampaian hasil analisa jabatan kepada Bupati;

10. Penyampaian Laporan Pelaksanaan Tugas dan Fungsi kepada Bupati;

11. Penyampaian LAKIP di bidang Pekerjaan Umum kepada Bupati;

12. Pembinaan kegiatan administrasi, kepegawaian, keuangan, dan rumah tangga di lingkungan Dinas Pekerjaan Umum;

13. Pembinaan, bimbingan dan pengawasan terhadap staf;

14. Penyusunan rencana strategis dan rencana kerja tahunan di lingkungan Dinas Pekerjaan Umum;

15. Pelaksanaan tugas lain yang diberikan oleh Bupati sesuai dengan tugas dan fungsinya.

Tugas pokok Sekretaris Dinas Pekerjaan Umum Kabupaten Sintang adalah membantu Kepala Dinas dalam bidang administrasi, ketatausahaan, aparatur, keuangan, arsip, perlengkapan serta melaksanakan perencanaan, pengaturan dan pengendalian peralatan, sedangkan yang menjadi Fungsinya adalah :

1. Penghimpunan, mengoordinasikan dan menyusun perencanaan dan program kerja Dinas Pekerjaan Umum;

2. Pengelolaan administrasi umum, kepegawaian, keuangan, arsip dan barang serta peralatan;

3. Pelaksanaan koordinasi penyusunan perencanaan kegiatan Pekerjaan Umum;

4. Penghimpunan peraturan, ketentuan dan dokumen yang berkaitan dengan pelaksanaan tugas;
5. Perencanaan dan penyelenggaraan kegiatan kesekretariatan, kepegawaian, keuangan, barang, peralatan dan memberikan pelayanan teknis administrasi kepada seluruh satuan organisasi Dinas Pekerjaan Umum;

6. Penghimpunan, penyusunan dan pengoordinasian program kerja dan laporan Dinas Pekerjaan Umum;

7. Penelitian dan penelaahan konsep atau naskah dinas serta dokumen lain yang akan diajukan kepada Kepala Dinas;

8. Pelaksanaan bimbingan, pengawasan, evaluasi dan memberi petunjuk serta arahan kepada Sub Bagian Keuangan dan Program, Sub Bagian Aparatur dan Umum dan Sub Bagian Perlengkapan;

9. Pendistribusian dan pengoordinasian tugas-tugas dari Kepala Dinas kepada para kepala bidang di Dinas Pekerjaan Umum;

10. Pemberian saran dan pertimbangan kepada Kepala Dinas baik secara tertulis maupun lisan diminta atau tidak; dan

11. Pelaksanaan tugas lain yang diberikan oleh Kepala Dinas sesuai dengan tugas dan fungsinya.

Sekretaris Dinas Pekerjaan Umum Kabupaten Sintang membawahi Kepala Sub Bagian Keuangan dan Program, Kepala Sub Bagian Aparatur Umum, dan Kepala Sub Bagian Perlengkapan. Tugas pokok Kepala Sub Bagian Keuangan dan Program pada Sekretariat Dinas Pekerjaan Umum Kabupaten Sintang adalah melaksanakan urusan penatausahaan keuangan dan perbendaharaan, pelaporan keuangan, menyusun rencana dan program kerja serta laporan kinerja Dinas Pekerjaan Umum, sedangkan yang menjadi 
Fungsinya adalah :

1. Penyusunan program kerja tahunan pada Sub Bagian Keuangan dan Program;

2. Pelaksanaan administrasi di bidang Keuangan dan Program Dinas Pekerjaan Umum;

3. Pengoordinasian dan pengawasan pelaksanaan administrasi dan teknis pembayaran gaji pegawai pada Dinas Pekerjaan Umum;

4. Pengoordinasian dan pengawasan pelaksanaan administrasi dan teknis operasional belanja pemeliharaan dan belanja modal sesuai dengan ketentuan yang berlaku sehingga dapat dibayarkan kepada pelaksana kegiatan;

5. Pembuatan usulan Pembuat Teknis Kegiatan (PTK) dan Pejabat Pembuat Komitmen(PPK) pada Dinas Pekerjaan Umum;

6. Pengoordinasian dan persiapan pembuatan administrasi pencairan keuangan berdasarkan ketentuan yang berlaku;

7. Penginventarisasian dan mempelajari semua peraturan perundang-undangan yang berhubungan dengan tugas keuangan dan program;

8. Persiapan, pengoordinasian dan penyusunan rencana strategis (Renstra), Rencana Kerja (Renja) dan Rencana Anggaran Satuan Kerja Dinas Pekerjaan Umum;

9. Pelaksnaaan dan pengelolaan urusan penatausahaan dan pertanggungjawaban keuangan Dinas Pekerjaan Umum;

10. Pengumpulan dan pengolahan data administrasi keuangan sebagai bahan laporan keuangan dan laporan pelaksanaan program kerja Dinas Pekerjaan Umum;

11. Pelaksanan verifikasi kelengkapan surat permintaan pembayaran yang diajukan oleh bendahara pengeluaran;
12. Penyiapan surat perintah membayar (SPM) belanja di lingkungan Dinas Pekerjaan Umum;

13. Penyelenggaraan verifikasi atas penerimaan di lingkungan Dinas Pekerjaan Umum;

14. Pelaksanaan akuntansi dan penyiapan laporan keuangan Dinas Pekerjaan Umum;

15. Pelaksanaan tugas lain yang diberikan oleh Sekretaris Dinas sesuai dengan tugas dan fungsinya.

Tugas pokok Kepala Sub Bagian Aparatur dan Umum pada Sekretariat Dinas Pekerjaan Umum Kabupaten Sintang adalah melaksanakan urusan surat menyurat, kearsipan, kepustakaan dan urusan administrasi kepegawaian Dinas Pekerjaan Umum, sedangkan yang menjadi Fungsinya adalah :

16. Penyusunan program kerja tahunan pada Sub Bagian Aparatur danUmum;

17. Pelaksanaan tugas di bidang Aparatur dan Umum;

18. Pelaksanaan urusan ketatausahaan (meneliti dan menelaah serta mengarsipkan surat-surat / naskah dinas yang telah di disposisi oleh Kepala Dinas);

19. Penyiapan bahan dan pelaksanaan penyelesaian LAKIP, Penetapan kinerja, pengawasan melekat, analisa jabatan Dinas Pekerjaan Umum dan laporan lainnya yang diperlukan pada Sekretaris Dinas;

20. Pelaksanaan kegiatan administrasi kepegawaian yang meliputi surat tugas, surat keputusan kepala dinas, cuti, daftar usulan kepangkatan, formasi dan bezzeting pegawai, gaji berkala, pensiun, laporan pajak-pajak pribadi (LP2P) dan kegiatan lain 
yang berkaitan dengan administrasi kepegawaian sesuai dengan peraturan perundang-undangan yang berlaku;

21. Penyiapan bahan laporan daftar hadir/ absensi pegawai Dinas Pekerjaan Umum;

22. Peningkatan sumber daya manusia guna peningkatan kinerja dinas;

23. Pelaksanaan pengolahan data, urusan surat menyurat, keprotokolan, humas, kearsipan dan kepustakaan;

24. Pelaksanaan bimbingan dan pengelolaan urusan administrasi kepegawaian Dinas Pekerjaan Umum;

25. Pelaksanaan inventarisasi dan mempelajari semua peraturan perundang-undangan yang berhubungan dengan tugas Aparatur dan Umum;

26. Pelaksanaan tugas lain yang diberikan oleh Sekretaris Dinas sesuai dengan tugas dan fungsinya.

Kepala Dinas Pekerjaan Umum

Kabupaten Sintang dari hasil wawancara dengan peneliti mengatakan bahwa berdasarkan tugas pokok tersebut, maka tata kerja di lingkungan Dinas Pekerjaan Umum Kabupaten Sintang menerapkan prinsip koordinasi, integrasi dan sinkronisasi secara vertikal dan horizontal baik di dalam lingkungan masing-masing dan antar satuan organisasi perangkat daerah serta dengan instansi vertikal di lingkungan Pemerintah Kabupaten Sintang sesuai dengan bidangnya. Selanjutnya, Kepala Dinas Pekerjaan Umum Kabupaten Sintang menjelaskan bahwa pejabat struktural di Dinas Pekerjaan Umum Kabupaten Sintang bertanggung jawab memimpin dan mengoordinasikan bawahannya masing-masing, memberikan bimbingan serta petunjuk pelaksanaan tugas bawahannya, wajib mengetahui dan mematuhi petunjuk, bertanggung jawab dan menyampaikan laporan kepada atasan masingmasing, wajib mengkoreksi dan mengkaji laporan yang diterima dan selanjutnya sebagai bahan pertimbangan lebih lanjut, serta wajib mengawasi bawahan masing-masing dan mengambil langkah-langkah dan tindakan bila terjadi penyimpangan-penyimpangan sesuai dengan peraturan yang berlaku.

Berkaitan dengan tata kerja Kepala Bidang dan Kepala UPTD, Kepala Dinas Pekerjaan Umum Kabupaten Sintang mengatakan bahwa Kepala Bidang dan Kepala UPTD menyampaikan laporan kepada Kepala Dinas dan Sekretaris Dinas untuk menyusun laporan berkala Dinas Pekerjaan Umum kepada Bupati.

Kepala Dinas Pekerjaan Umum Kabupaten Sintang dari hasil wawancara dengan peneliti mengatakan bahwa Dinas Pekerjaan Umum Kabupaten Sintang dalam melaksanakan tugas pokok dan fungsinya di dukung oleh 94 orang pegawai dengan komposisi sebagai berikut :

27. Dari segi Kepangkatan/Golongan Ruang, terdiri dari :
a. Golongan I, sebanyak orang. 
b. Golongan II, sebanyak 41 orang.

c. Golongan III, sebanyak 48 orang.

d. Golongan IV, sebanyak 4 orang.

28. Tenaga Honorer Rutin (Data Base) dengan jumlah 9 orang, dan

29. Tenaga Kontrak yang ditempatkan pada bidang-bidang atau kegiatan yang ada.

Selain dukungan pegawai, tersedianya sarana dan prasarana yang memadai juga merupakan sumber daya yang dapat mendukung kelancaran pelaksanaan tugas. Berdasarkan pengamatan peneliti di Dinas Pekerjaan Umum Kabupaten Sintang bahwa sarana dan prasarana yang tersedia di Dinas Pekerjaan Umum Kabupaten Sintang meliputi : 1). Gedung kantor; 2). Gedung aula; 3). Workshop alat berat; 4). Laboratorium; 5). Kendaraan dinas; 6). Peralatan komputer; dan 7). Peralatan pendukung lainnya yang digunakan untuk lapangan meliputi : 1 (satu) unit exsavator tahun 2009, 1 (satu) unit motor greader tahun 1998, 1 (satu) unit whel loader tahun 1998, 4 (empat) unit dumtruck tahun 1998, 3 (tiga) unit triwil tahun 1998, 1 (satu) unit buldozer tahun 1998, dan 5 (lima) unit sepeda motor dinas tahun 2012.

\section{B. Disiplin Kerja Tepat Waktu}

Terkait dengan jam masuk kerja Pegawai Negeri Sipil(PNS) di Dinas Pekerjaan Umum Kabupaten Sintang, Kepala Dinas
Pekerjaan Umum Kabupaten Sintang kepada peneliti mengatakan bahwa berdasarkan ketentuan dalam Peraturan Menteri Dalam Negeri Republik Indonesia Nomor 4 Tahun 2013 Tentang Disiplin Kerja Pegawai Negeri Sipil Di Lingkungan Kementerian Dalam Negeri dinyatakan bahwa jam kerja PNS mulai hari Senin sampai dengan hari Jumat dengan ketentuan bahwa jam kerja PNS pada hari Senin sampai dengan hari Kamis, jam masuk kerja Pukul 07.30 dan jam pulang kerja Pukul 16.00 waktu setempat dan pada hari Jum'at, jam masuk kerja Pukul 07.30 dan jam pulang kerja 16.30 waktu setempat.

Menurut Kepala Dinas Pekerjaan Umum Kabupaten Sintang bahwa jam kerja disesuaikan dengan PNS yang melakukan pekerjaan di luar kantor dan di luar ketentuan jam kerja antara lain mengikuti diklat, tugas belajar, menghadiri rapat, perjalanan dinas dan tugas lain yang berkaitan dengan kedinasan.

Begitu pula jam kerja pada bulan Ramadhan diatur tersendiri pada setiap bulan Ramadhan yang pelaksanaannya mengacu pada ketentuan yang berlaku. Disamping itu, jam istirahat PNS pada hari Senin sampai dengan hari Kamis mulai pukul 12.00 sampai dengan 13.00 waktu setempat dan pada hari Jum'at mulai pukul 11.30 sampai dengan 13.00 waktu setempat. 
Tabel 3. Hari dan Jam Kerja Pegawai Negeri

Sipil.

\begin{tabular}{|c|c|c|c|c|}
\hline Hari & $\begin{array}{c}\text { Jam } \\
\text { Masuk } \\
\text { Kerja }\end{array}$ & $\begin{array}{l}\text { Jam } \\
\text { Pulang } \\
\text { Kerja }\end{array}$ & $\begin{array}{c}\text { Jam } \\
\text { Istirahat }\end{array}$ & $\begin{array}{l}\text { Jam Pada } \\
\text { Bulan } \\
\text { Ramadhan }\end{array}$ \\
\hline $\begin{array}{l}\text { Senin, } \\
\text { Selasa, } \\
\text { Rabu, } \\
\text { Kamis }\end{array}$ & $\begin{array}{c}\text { Pukul } \\
07.30 \\
\text { waktu } \\
\text { setempat }\end{array}$ & $\begin{array}{c}\text { Pukul } \\
16.00 \\
\text { waktu } \\
\text { setempat }\end{array}$ & $\begin{array}{c}\text { Pukul } 12.00 \\
\text { sampai } \\
\text { dengan } \\
13.00 \text { waktu } \\
\text { setempat }\end{array}$ & $\begin{array}{l}\mathrm{D} \text { i a } \mathrm{t} \text { u } \mathrm{r} \\
\text { terse } \mathrm{ndi} \text { ri } \\
\text { pada setiap } \\
\text { bulan } \quad \text { Ra- } \\
\text { madhan yang }\end{array}$ \\
\hline Jum & $\begin{array}{c}\text { Pukul } \\
07.30 \\
\text { waktu } \\
\text { setempat }\end{array}$ & $\begin{array}{c}\text { Pukul } \\
16.30 \\
\text { waktu } \\
\text { setempat }\end{array}$ & $\begin{array}{c}\text { Pukul } 11.30 \\
\text { sampai } \\
\text { dengan } \\
\text { 13.00 waktu } \\
\text { setempat }\end{array}$ & $\begin{array}{l}\text { pelaksanaan- } \\
\text { nya mengacu } \\
\text { pada keten- } \\
\text { tuan yang } \\
\text { berlaku }\end{array}$ \\
\hline
\end{tabular}

Sumber Data : Kutipan Wawancara Peneliti dengan Kepala Dinas Pekerjaan Umum Kabupaten Sintang.

Terkait dengan jam kerja, Kepala Dinas Pekerjaan Umum Kabupaten Sintang kepada peneliti mengatakan bahwa : para pegawai yang ada di Dinas Pekerjaan Umum Kabupaten Sintang selalu mentaati jam kerja yang telah ditentukan, yaitu untuk hari Senin hingga Kamis, para pegawai selalu tiba di kantor Pukul 07.30 Wib dan pulang kantor pada Pukul 16.00 Wib. Sedangkan untuk hari Jumat, tiba di kantor Pukul 07.30 Wib dan pulang kantor 16.30 Wib. Kepala Dinas Pekerjaan Umum Kabupaten Sintang menjelaskan bahwa para pegawai setibanya di kantor mengisi daftar hadir yang sudah disiapkan. Begitu pula saat pulang kantor, para pegawai juga mengisi daftar ceklist yang sudah disiapkan. Namun menurut Kepala Dinas Pekerjaan Umum Kabupaten Sintang bahwa tidak semua pegawai setelah mengisi daftar hadir lalu kemudian berada di kantor, akan tetapi ada sejumlah pegawai setelah mengisi daftar hadir selanjutnya melaksanakan tugasnya di luar kantor.

Kepala Dinas Pekerjaan Umum Kabupaten Sintang mengatakan bahwa para pegawai yang selalu melaksanakan tugasnya di kantor adalah pegawai yang memiliki jabatan yaitu : Sekretaris, Kepala-kepala Sub Bagian, Kepala-kepala Bidang, dan Kepalakepala Seksi, sedangkan para pegawai yang melaksanakan tugasnya di luar kantor adalah pegawai-pegawai yang menerima tugas kedinasan untuk melaksanakan tugas di luar kantor. Namun demikian, semua pegawai itu tetap datang ke kantor sesuai jam kerja yang ditentukan apabila tidak sedang dinas luar.

Berdasarkan hasil observasi yang dilakukan peneliti di kantor Dinas Pekerjaan Umum Kabupaten Sintang (tanpa diketahui oleh setiap aparatur di kantor tersebut bahwa peneliti sedang melakukan observasi) terlihat bahwa Kepala Dinas, Sekretaris Dinas, semua kepala sub bagian di Sekretariat Dinas, semua kepala bidang, semua kepala seksi pada tiaptiap bidang, dan semua staf datang ke kantor pada Pukul 07.30 Wib, begitu juga pada saat pulang kerja, mereka pulang pada Pukul 16.00 Wib. Bahkan pada keesokkan harinya juga mereka tetap datang dan pulang kerja tepat waktu. Pada hari Selasa itu, peneliti berhasil 
mewawancarai subjek penelitian.

Berdasarkan hasil wawancara peneliti dengan Kepala Dinas Pekerjaan Umum Kabupaten Sintang diperoleh penjelasan bahwa pegawai untuk datang dan pulang kantor tepat waktu karena dirinya merupakan atasan yang harus menjadi contoh teladan bagi setiap pegawai bawahannya. Oleh karena itu, setiap kali dirinya memandang bahwa ia seorang atasan bagi bawahannya, maka disitulah muncul sebuah dorongan atau terdisiplin untuk datang dan pulang kantor tepat waktu, atau singkatnya terdisiplin dari rasa malu terhadap para pegawai bawahannya bila datang dan pulang kantor tidak tepat waktu. Jadi, menurutnya disiplin itu datang ke dalam dirinya karena rasa malu terhadap para pegawai bawahannya.

Selain itu, berdasarkan hasil wawancara peneliti dengan Sekretaris Dinas Pekerjaan Umum Kabupaten Sintang diperoleh penjelasan bahwa munculnya disiplin untuk datang dan pulang kantor tepat waktu karena adanya peraturan kepegawaian yang harus ditaati, sebab bila peraturan itu dilanggar, maka akan dikenakan sanksi. Jadi, menurutnya disiplin itu datang ke dalam dirinya karena takut dikenakan sanksi.

Selainitu,berdasarkanhasilwawancara peneliti dengan Kepala Bidang di lingkungan Dinas Pekerjaan Umum Kabupaten Sintang (hanya ditujukan kepada Kepala Bidang Bina Marga sebagai perwakilan dari kepala bidang lainnya) diperoleh penjelasan bahwa munculnya disiplin untuk datang dan pulang kantor tepat waktu karena adanya prestasi yang harus dikejar oleh seorang PNS. Salah satu prestasi yang harus dikejar seorang PNS adalah harus mentaati jam datang dan pulang kerja sesuai peraturan yang berlaku. Menurutnya, kalau seorang PNS berprestasi maka mudah untuk urusan kenaikan pangkat dan memperoleh karir. Jadi, menurutnya disiplin itu datang ke dalam dirinya karena sebuah prestasi yang harus dikejar oleh seorang PNS.

Selain itu, berdasarkan hasil wawancara peneliti dengan Kepala Sub Bagian di lingkungan Dinas Pekerjaan Umum Kabupaten Sintang (hanya ditujukan kepada Kepala Sub Bagian Aparatur dan Umum sebagai perwakilan dari kepala sub bagian lainnya) mengatakan bahwa munculnya disiplin untuk datang dan pulang kantor tepat waktu karena adanya tanggungjawab pekerjaan sebagai PNS. Menurutnya, menjadi seorang PNS harus siap lahir dan batin, sebab PNS adalah orang yang selalu diperintah berdasarkan peraturan yang ada. Kalau diperintah untuk datang dan pulang kantor sesuai jamnya, maka hal itu harus dilaksanakan dengan penuh tanggung jawab, 
karena itu sudah menjadi tuntutan pekerjaan sebagai seorang PNS. Jadi, menurutnya disiplin itu datang ke dalam dirinya karena adanya tanggungjawab pekerjaan sebagai PNS.

Selainitu,berdasarkanhasilwawancara peneliti dengan Kepala Seksi di lingkungan Dinas Pekerjaan Umum Kabupaten Sintang (hanya ditujukan kepada Kepala Seksi Tata Kota sebagai perwakilan dari kepala seksi lainnya) mengatakan bahwa munculnya disiplin untuk datang dan pulang kantor tepat waktu karena banyaknya kegiatan, disatu sisi tanggungjawabnya sebagai PNS yang harus bekerja di kantor, dan di sisi lainnya, punya tanggungjawab dalam mengurus rumah tangga. Menurutnya, kedua tanggung jawab tersebut membuat dirinya terdisiplin untuk datang dan pulang kantor tepat waktu, sebab bila datang terlambat baik datang dan pulang kantor, maka dapat mengabaikan kedua tanggung jawab tersebut, urusan kantor menjadi tidak efektif begitu juga urusan rumah tangga yang sudah pasti menjadi tidak efektif. Sebaliknya, bila datang ke kantor tepat waktu namun pulang kantor lebih awal maka meskipun urusan rumah tanggamenjadi maksimal namun urusan kantor akan menjadi kurang maksimal. Apalagi bila datang ke kantor terlambat namun pulangnya tepat waktu maka urusan kantor juga akan menjadi kurang maksimal. Jadi, menurutnya disiplin itu datang ke dalam dirinya karena adanya 2 (dua) tanggungjawab baik tuntutan sebagai sebagai PNS maupun urusan rumah tangga.

Selain itu, berdasarkan hasil wawancara peneliti dengan Staf di lingkungan Dinas Pekerjaan Umum Kabupaten Sintang (ditujukan kepada dua orang staf). Mereka sama-sama mengatakan bahwa munculnya disiplin untuk datang dan pulang kantor tepat waktu karena takut ditegur pimpinan, sebab menurut mereka, pimpinannya tidak segansegan menegur bila melihat stafnya tidak mematuhi jam kerja. Jadi, menurut mereka, disiplin itu datang ke dalam diri mereka masing-masing karena takut ditegur pimpinan.

Berdasarkan hasil obvervasi dan hasil wawancara yang diperoleh tersebut dapat diperoleh sebuah kesimpulan, bahwa pegawai di Dinas Pekerjaan Umum Kabupaten Sintang dalam melaksanakan ketentuan jam kerja didasarkan pada disiplin yang tersimpan dalam diri setiap pegawai tersebut. Disiplindisiplin untuk kerja tepat waktu tersebut sangat beragam dengan 6 (enam) dorongan (disiplin), yaitu : 1). Rasa malu terhadap para pegawai bawahannya, 2). Takut dikenakan sanksi, 3). Sebuah prestasi yang harus dikejar oleh seorang PNS, 4). Tanggungjawab pekerjaan sebagai PNS, 5). Adanya 2 (dua) tanggungjawab baik tuntutan sebagai sebagai 
PNS maupun urusan rumah tangga, dan 6).

Takut ditegur pimpinan.

Berdasarkan hasil penelitian tersebut, peneliti berpendapat bahwa pada dasarnya seorang bekerja karena keinginan memenuhi kebutuhan hidupnya. Dorongan keinginan pada diri seseorang dengan orang yang lain berbeda sehingga perilaku manusia cenderung beragam di dalam bekerja, sebagaimana dalam Bab II Kajian Pustaka terdahulu mengemukakan pendapat ahli yang mengatakan bahwa disiplin mempersoalkan bagaimana cara mengarahkan daya dan potensi agar bekerja mencapai tujuan yang ditentukan.

\section{Disiplin Menyelesaikan Pekerjaan}

Terkait dengan disiplin menyelesaikan pekerjaan, Kepala Dinas Pekerjaan Umum Kabupaten Sintang saat diwawancarai peneliti mengatakan bahwa ketepatan dalam menjalankan tugas baik ketepatan mengerjakan tugas dengan tata cara yang ditetapkan, kerapian dan ketepatan dalam waktu penyelesaian pekerjaan sangat penting. Menurut Kepala Dinas Pekerjaan Umum Kabupaten Sintang bahwa disiplin kerja pegawai harus ditingkatkan secara terusmenerus. Dengan adanya disiplin yang baik dapat meningkatkan kinerja pegawai. Disiplin kerja berkaitan erat dengan pegawai karena semakin baik disiplin pegawai, semakin tinggi prestasi kerja yang dapat dicapai. Seorang pegawai dikatakan mempunyai kinerja yang baik apabila dalam melaksanakan pekerjaan sesuai dengan cara kerja yang telah ditentukan, pekerjaannya dikerjakan dan diselesaikan sesuai dengan waktu yang telah ditentukan. Ketepatan waktu dalam mengerjakan berbagai pekerjaan mencerminkan tingkat kedisiplinan yang dimiliki oleh Pegawai Negeri Sipil sehingga sangat berpengaruh terhadap output yang akan dihasilkan kinerjanya. Dalam melaksanakan tugas-tugas atau pekerjaan disesuaikan tugas pokok dan fungsinya. Ketepatan waktu dalam penyelesaian tugas merupakan prioritas utama pegawai sehingga dapat meningkatkan kinerjanya. Upaya peningkatan disiplin pegawai salah satunya dipengaruhi oleh disiplin. Disiplin dapat menjadi pendorong seorang pegawai melaksanakan suatu kegiatan guna mendapatkan hasil yang terbaik. Oleh karena itulah tidak heran jika pegawai yang mempunyai disiplin kerja yang tinggi biasanya mempunyai kinerja yang tinggi pula. Untuk itu disiplin kerja pegawai perlu juga dibangkitkan dan ditingkatkan agar pegawai dapat menghasilkan kinerja yang terbaik.

Berdasarkan hasil wawancara peneliti dengan Kepala Dinas Pekerjaan Umum Kabupaten Sintang diperoleh 
penjelasan bahwa munculnya disiplin untuk menyelesaikan pekerjaan karena tidak ingin pekerjaan itu menumpuk dan berlarut-larut. Jadi, menurutnya disiplin itu datang ke dalam dirinya karena adanya pekerjaan yang harus diselesaikan.

Selain itu, berdasarkan hasil wawancara peneliti dengan Sekretaris Dinas Pekerjaan Umum Kabupaten Sintang diperoleh penjelasan bahwa munculnya disiplin untuk menyelesaikan pekerjaan karena takut lupa. Menurutnya, bila ada pekerjaan kantor yang bisa diselesaikan segera, namun pekerjaan itu ditinggalkan ditengah jalan atau belum tuntas dikerjakan dan berharap besoknya diselesaikan, maka dikuatirkan akan lupa dengan pekerjaan tersebut. Jadi menurutnya, bila dirinya mendapat pekerjaan yang dapat selesai untuk hari itu, maka hari itu juga harus dikerjakan sampai selesai, kalau tidak maka dikuatirkan akan lupa dengan pekerjaan terebut.

Selainitu,berdasarkanhasilwawancara peneliti dengan Kepala Bidang di lingkungan Dinas Pekerjaan Umum Kabupaten Sintang (hanya ditujukan kepada Kepala Bidang Bina Marga sebagai perwakilan dari kepala bidang lainnya) diperoleh penjelasan bahwa munculnya disiplin untuk menyelesaikan pekerjaan karena pekerjaan datang silih berganti sehingga setiap pekerjaan yang datang, harus diselesaikan segera mungkin. Jadi, menurutnya disiplin itu datang ke dalam dirinya karena pekerjaan datang silih berganti. Selain itu,berdasarkan hasil wawancara peneliti dengan Kepala Sub Bagian di lingkungan Dinas Pekerjaan Umum Kabupaten Sintang (hanya ditujukan kepada Kepala Sub Bagian Aparatur dan Umum sebagai perwakilan dari kepala sub bagian lainnya) mengatakan bahwa munculnya disiplin untuk menyelesaikan pekerjaan karena adanya tanggungjawab pekerjaan sebagai PNS. Menurutnya, menjadi seorang PNS harus siap lahir dan batin, sebab PNS adalah orang yang selalu diperintah oleh atasan. Kalau diperintah oleh atasan untuk menyelesaikan pekerjaan, maka hal itu harus dilaksanakan dengan penuh tanggung jawab, karena itu sudah menjadi tuntutan pekerjaan sebagai seorang PNS. Jadi, menurutnya disiplin itu datang ke dalam dirinya karena adanya perintah dari atasan.

Selain itu, berdasarkan hasil wawancara peneliti dengan Kepala Seksi di lingkungan Dinas Pekerjaan Umum Kabupaten Sintang (hanya ditujukan kepada Kepala Seksi Tata Kota sebagai perwakilan dari kepala seksi lainnya) mengatakan bahwa munculnya disiplin untuk menyelesaikan pekerjaan karena adanya sistem penilaian yang diterapkan di kantor terhadap para 
pegawai atau biasa dikenal dengan istilah Daftar Penilaian Pelaksanaan Pekerjaan atau DP3. Jadi, menurutnya disiplin itu datang ke dalam dirinya karena takut dinilai buruk dalam DP3 yang dapat mempengaruhi jenjang karirnya.

Selain itu, berdasarkan hasil wawancara peneliti dengan Staf di lingkungan Dinas Pekerjaan Umum Kabupaten Sintang (ditujukan kepada dua orang staf). Mereka sama-sama mengatakan bahwa munculnya disiplin untuk menyelesaikan pekerjaan karena takut ditegur pimpinan, sebab menurut mereka, pimpinannya tidak segansegan menegur bila melihat stafnya tidak menyelesaikan pekerjaan atau sering menunda pekerjaan yang seharusnya bisa dikerjakan segera. Jadi, menurut mereka, disiplin itu datang ke dalam diri mereka masing-masing karena takut ditegur pimpinan.

Berdasarkan hasil obvervasi dan hasil wawancara yang diperoleh tersebut dapat diperoleh sebuah kesimpulan, bahwa pegawai di Dinas Pekerjaan Umum Kabupaten Sintang dalam menyelesaikan pekerjaan didasarkan pada disiplin yang tersimpan dalam dirisetiap pegawai tersebut. Disiplin-disiplin untuk menyelesaikan pekerjaan tersebut sangat beragam dengan 6 (enam) dorongan (disiplin), yaitu : 1). Adanya pekerjaan yang harus diselesaikan, 2). Takut lupa dengan pekerjaan yang sedang dikerjakan, 3). Pekerjaan yang datang silih berganti, 4). Adanya perintah dari atasan, 5). Takut dinilai buruk dalam DP3 yang dapat mempengaruhi jenjang karirnya, dan 6). Takut ditegur pimpinan.

Berdasarkan hasil penelitian tersebut, peneliti berpendapat bahwa pada dasarnya seorang bekerja karena keinginan memenuhi kebutuhan hidupnya. Dorongan keinginan pada diri seseorang dengan orang yang lain berbeda sehingga perilaku manusia cenderung beragam di dalam bekerja termasuk didalamnya menyelesaikan pekerjaan, sebagaimana dalam Bab II Kajian Pustaka terdahulu mengemukakan pendapat ahli yang mengatakan bahwa disiplin mempersoalkan bagaimana cara mengarahkan daya dan potensi agar bekerja mencapai tujuan yang ditentukan.

\section{Simpulan}

Berdasarkan hasil penelitian yang telah dikemukakan maka dapat disimpulkan bahwa disiplin kerja tepat waktu para pegawai di Dinas Pekerjaan Umum Kabupaten Sintang dalam melaksanakan ketentuan jam kerja didasarkan pada disiplin yang tersimpan dalam diri setiap pegawai tersebut. Disiplindisiplin untuk kerja tepat waktu tersebut sangat beragam dengan 6 (enam) dorongan (disiplin), yaitu : 1). Rasa malu terhadap para 
pegawai bawahannya, 2). Takut dikenakan sanksi, 3). Sebuah prestasi yang harus dikejar oleh seorang PNS, 4). Tanggungjawab pekerjaan sebagai PNS, 5). Adanya 2 (dua) tanggungjawab baik tuntutan sebagai sebagai PNS maupun urusan rumah tangga, dan 6). Takut ditegur pimpinan, sedangkan disiplin menyelesaikan pekerjaan para pegawai di Dinas Pekerjaan Umum Kabupaten Sintang dalam menyelesaikan pekerjaan didasarkan pada disiplin yang tersimpan dalam diri setiap pegawai tersebut. Disiplin-disiplin untuk menyelesaikan pekerjaan tersebut juga sangat beragam yang terdiri dari 6 (enam) dorongan (disiplin), yaitu : 1). Adanya pekerjaan yang harus diselesaikan, 2). Takut lupa dengan pekerjaan yang sedang dikerjakan, 3). Pekerjaan yang datang silih berganti, 4). Adanya perintah dari atasan, 5). Takut dinilai buruk dalam DP3 yang dapat mempengaruhi jenjang karirnya, dan 6). Takut ditegur pimpinan. Berdasarkan kesimpulan yang telah dikemukakan tersebut maka saran peneliti adalah : a). Setiap pegawai negeri sipil di Dinas Pekerjaan Umum Kabupaten Sintang dalam melaksanakan tugas pokok dan fungsinya harus lebih tedisiplin lagi dalam bekerja sebab bila disiplin yang sedikit (minim) tidak dapat memacu semangat pekerjaan, dan b). Dinas Pekerjaan Umum Kabupaten Sintang dapat menggunakan hasil penelitian skripsi ini sebagai bahan evaluasi bagi setiap pegawai untuk memiliki disiplin yang lebih banyak lagi.

\section{DAFTAR PUSTAKA}

\section{Buku-Buku :}

As'ad, Moch. 1995. Psikologi Industri. Jakarta : Liberty.

Berelson, Bernard dan Stainer, Gary. 2002. Manajemen Sumber Daya Manusia. Jakarta : Rineka Cipta.

Danim, Sudarman. 2001. Disiplin, Kepemimpinan dan Efektivitas Kelompok. Jakarta : Penerbit Rineka Cipta.

Hasibuan, Malayu S.P. 2006. Manajemen Dasar, Pengertian, dan Masalah, Edisi Revisi. Jakarta : Bumi Aksara.

Notoatmodjo, Soekidjo. 2005. Pengembangan Sumber Daya Manusia. Jakarta : Rineka Cipta.

Pace, R. Wayne dan Faules, Don F. 1998. Komunikasi Organisasi : Strategi Meningkatkan Kinerja Perusahaan. Penerjemah Deddy Mulyana. Bandung : Remaja Rosdakarya.

Purwanto, Djoko. 2006. Komunikasi Bisnis. Jakarta : Erlangga.

Sardiman, A.M. 2007. Interaksi dan Disiplin Belajar Mengajar. Jakarta : Raja Grafindo Persada.

Sastrohadiwiryo, Siswanto B. 2003. Manajemen Tenaga Kerja Indonesia : Pendekatan Administratif dan Operasional. Jakarta : Bumi Aksara.

Siagian, Sondang P. 1985. Organisasi Kepemimpinan Perilaku Administrasi.Jakarta : Gunung Agung. 
2006. Manajemen Sumber

Daya Manusia. Edisi Satu. Cetakan

Ketigabelas. Jakarta : Bumi Aksara.

Steers, Richard M. dan Porter, Lyman W. 1991.

Motivation and Work Behaviour.

5th ed. New York : McGraw-Hill.

Uno, Hamzah B. 2008. Model Pembelajaran :

Menciptakan Proses Belajar Mengajar Yang Kreatif dan Efektif. Jakarta : Bumi Aksara.

Wahjosumidjo. 2001. Kepemimpinan dan

Disiplin. Jakarta : Ghalia Indonesia.

Winardi. 2000. Kepemimpinan Dalam Manajemen. Jakarta : Rineka Cipta.

Wursanto. 1987. Manajemen Kepegawaian. Yogyakarta : Kanisius.

\section{$\underline{\text { Peraturan Perundang-undangan }}$}

Undang-Undang Nomor 43 Tahun 1999 tentang Perubahan Atas Undang-Undang Nomor 8 Tahun 1974 Tentang Pokok-Pokok Kepegawaian.

Peraturan Pemerintah Nomor 53 Tahun 2010 tentang Disiplin Pegawai Negeri Sipil.

Peraturan Menteri Dalam Negeri Republik Indonesia Nomor 4 Tahun 2013 Tentang Disiplin Kerja Pegawai Negeri Sipil Di Lingkungan Kementerian Dalam Negeri. 